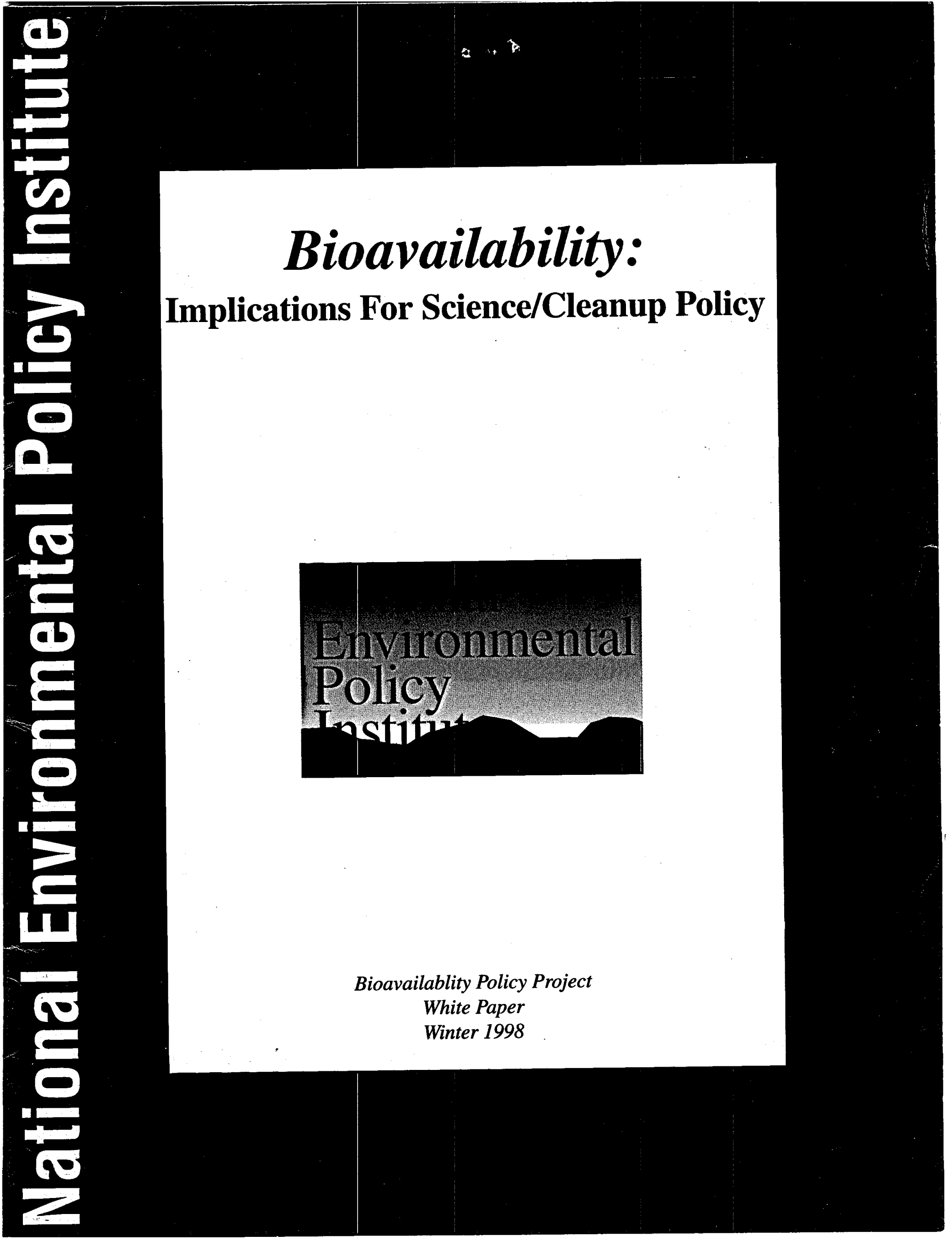




\section{About the}

\section{National Environmental Policy Institute}

The National Environmental Policy Institute (NEPI) is a non-profit, bipartisan organization of environmental leaders. It advances new ideas for developing environmental policies based on sound science, consideration of risks, costs and benefits, and the involvement of new constituencies. It strives to build consensus for change.

At the heart of NEPI's mission is its commitment to providing a substantive framework for improving environmental policy and management. It draws upon the collective skill, experience and knowledge of elected officials, industry representatives, government policy-makers, academics and members of the environmental and scientific communities.

NEPI is dedicated to establishing realistic environmental priorities and helping to focus the national environmental debate. Through its communications and out reach programs, NEPI has been successful in providing a forum for exchange and understanding among those involved in the environmental policy process as well as facilitating stakeholder dialogue and public education on the major environmental issues of our time.

For more information about NEPI or its projects or to order additional copies of this publication, please call (202) 857-4784 or consult NEPI's website at www.nepi.org. 
This report was prepared as an account of work sponsored by an agency of the United States Government. Neither the United States Government nor any ageacy thereof, nor any of their employees, makes any warranty, express or implied, or essumes any legal liability or responsibility for the accuracy, completeness, or usefulness of any information, apparatus, product, or process disclosed, or represeats that its use would not infringe privately owned rights. Reference herein to any specific commercial product, process, or service by trade name, trademark, manufacturer, or otherwise does not necessarily constitute or imply his endorsement, recom. mendation, or favoring by the United States Government or any agency thereof. The riews and opinions of authors expressed herein do not necessarily state or reflect those of the United States Government or any agency thereof. 


\section{DISCLAIMER}

Portions of this document may be illegible in electronic image products. Images are produced from the best available original document. 


\section{Table of Contents}

About the Project

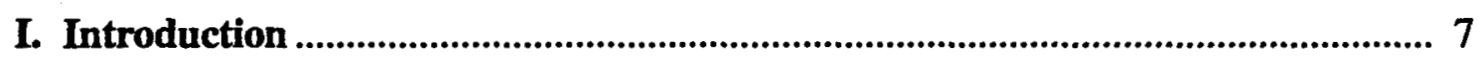

A. Key Points and Perspective ............................................................................. 7

B. A Tool For Better Decision-Making ........................................................... 8

II. Snapshot of the Current Risk Paradigm ............................................................. 10

III. Snapshot of the Current Decision Paradigm ....................................................... 12

IV. Overview of Scientific Concepts ............................................................................. 14

A. General Soils/Organics ............................................................................ 15

B. General Sediments/Organics and Metals .................................................... 18

V. Application/Implication of Bioavailability to Enviromental Cleanup

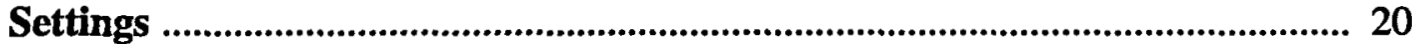

A. Synopsis of Illustrative Case Study .......................................................... 21

VI. Conclusions and Recommendations .......................................................... 23

A. Findings ................................................................................................ 23

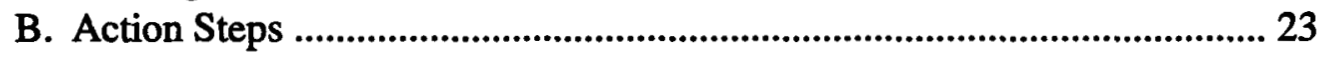

C. Scientific Needs ......................................................................................... 24

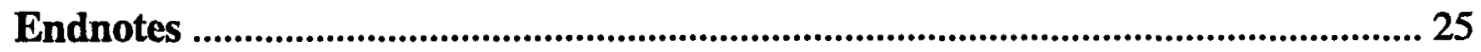

Appendix A

Bioavailability Policy Project Members ................................................................ 27

Appendix B

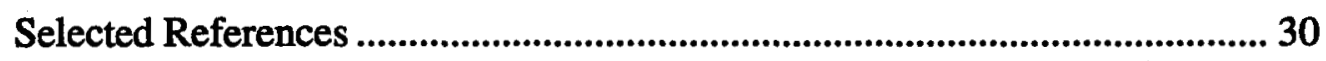

Appendix C

Additional References ........................................................................................ 32 


\section{About the Project}

The Bioavailability Policy Project (BPP) stemmed from the parent How Clean is Clean? (HCIC) Working Group, an effort involving over 150 public and private leaders aimed at creating a framework for improving our nation's cleanup programs. The primary focus areas or "sectors" of the HCIC Working Group have been cleanup and corrective action, federal facilities, brownfields and chemical emissions.

The bioavailability issue came to NEPI's attention in 1994 through some of the scientists involved with NEPI and the HCIC Working Group, principally Dr. Thomas Roose and David Linz of the Gas Research Institute, Dr. Dave Nakles of ReTec, Inc. and Dr. Raymond Loehr at the University of Texas at Austin. At an NEPI sponsored "congressional roundtable" on HCIC and Superfund for relevant congressional committee staff, Linz gave a presentation on the bioavailability issue which generated much interest.

Bioavailability was also a key component at a 1995 NEPI national symposium on brownfields involving a cross-section of leadership in policy, politics and science. That effort led to a policy study entitled The Environmental Impact of Soil Contamination: Bioavailability, Risk Assessment, and Policy Implications, authored by Dr. Loehr and published jointly by NEPI and the Reason Public Policy Institute. This publication served as an important baseline for discussions in the BPP.

With respect to data contributing to risk assessment and remediation decisions, the concept of bioavailability is fundamental to "defining environmentally acceptable endpoints." Bioavailability analysis is currently being used by regulators and others in the field on an ad hoc basis. While bioavailability is not new to many scientists, the issue has only recently received serious consideration from regulators and policy makers. Given the enormous impact this emerging science may have on our national cleanup policy and the current Superfund, brownfields, and corrective action debates, the relatively minor attention this issue received was surprising.

In September 1996, NEPI formed the BPP Working Group involving approximately 75 public and private leaders from the scientific community, academia, government and industry. Under the guidance of NEPI Chairman Don Ritter and Project Director Don R. Clay, former EPA assistant administrator for Solid Waste and Emergency Response, the Working Group aimed to create opportunities to enhance the development of the science of bioavailability and help move this science from the laboratory into practice. To obtain broad appreciation as to when and how bioavailability can be incorporated into risk assessment and cleanup decisions, the project includes regulators, policy makers, members of the regulated community and scientists from a variety of disciplines and backgrounds.

The overall goal of the project is to educate the public and policy makers at all levels on the stateof-the-science on bioavailability, how it should be incorporated into policy decisions on risk assessment and cleanup; and to further the understanding of regulators in making such policy decisions in the future. 
Project objectives include:

- Communicate the concept of bioavailability. Create a coherent set of messages about the concept of bioavailability and establish an awareness among the public and key policy makers at the federal, congressional and state level of the need to incorporate this knowledge into regulatory cleanup decision-making, under certain conditions.

- Demonstrate its capability as a risk assessment tool. Show current methods for assessing bioavailability and identify tools and models for incorporating this knowledge into the decision-making process.

- Demonstrate application to risk management. Give actual or hypothetical examples to illustrate application and facilitate understanding; and suggest policy approaches that make sense for risk analysis and remediation design.

- Focus research agenda. Determine the needs of regulators and local cleanup decisionmakers so as to help focus the research agenda and advance the state of the science further.

- Launch a national policy dialogue on bioavailability. Utilize a variety of communication tools and outreach activities to facilitate a broader dialogue among scientists, regulators and policy-makers involved in remedial decisions.

The BPP Working Group held several meetings between the Fall of 1996 and the Summer of 1997. In addition to providing analysis and recommendations that were essential to this white paper, the Working Group was instrumental in the development of a number of activities that were critical to project communication and outreach, and obtaining broader input to the Working Group process. These activities are summarized below.

On November 13, 1996, NEPI held a "Window on Washington" Roundtable entitled Cleaning $\boldsymbol{U}_{\boldsymbol{p}}$ in an Era of Devolution. In a panel on "Bioavailability - A New Definition for Clean?", a multidisciplinary group of six scientists and environmental managers of different backgrounds elaborated on the science of bioavailability and how the science could be used to illuminate innovation and expedite cleanup at the state and local levels. The dialogue was most fruitful as panel members engaged in discussion with state, local and community leaders and representative on other panels.

In March 1997, the BPP Working Group produced a briefing paper on bioavailability that was used to stimulate discussion in outreach meetings with EPA staff, congressional staff and others. Further investigation led to a draft white paper in May 1997 entitled Bioavailability: Implications for Science/Cleanup Policy. The draft white paper served as a vehicle for discussion in NEPI's national forum on bioavailability and feedback into the Working Group process.

On June 11, 1997, the National Environmental Policy Institute (NEPI) convened the first national conference on bioavailability in Washington, D.C. Bioavailability: The Policy Impact of Emerging Science brought together scientists, regulators and policy-makers to aid in building a bridge between 
science and regulation on the use of bioavailability as a consideration in cleanup decisions. The goal of the program was to create opportunities to enhance the development of the science of bioavailability and generate momentum and acceptance for incorporating cutting edge science into risk assessment and cleanup decisions.

NEPI hosted this conference to provide a logical and scientifically sound presentation of information on bioavailability to the public, regulators and other policy makers. Participants focused on four major aspects of bioavailability: 1) the state-of-the-science; 2) moving this science from the laboratory into practice; 3) bioavailability as a feature of national cleanup policy; and 4) research directions for the future.

This conference was unique in the context it provided to understand the issue of bioavailability. Speakers and panelists included basic and applied researchers of different scientific disciplines from academia, industry, and regulatory agencies; and key decision-makers in federal and state agencies and Congress that must use and/or understand the impact of this information.

NEPI has published the proceedings of this conference under separate cover and we encourage readers to consult it as a companion to this document : (1) to garner specifics details on research discussed, tests devised or identified as needed; and (2) to appreciate the trend and tenor of this multi-perspective debate.

Lastly, to gain a practical / implementation-oriented perspective on bioavailability, NEPI is working with remedial project managers and others in the field in an effort to develop a Bioavailability Field Guide that will have broad application to a variety of environmental managers seeking to incorporate this information in their site characterization and cleanup strategies.

At the time of this writing, bioavailability language has been incorporated on some four occasions in the latest Superfund reauthorization effort, H.R. 3000.

The pages that follow represent the findings and recommendations of the Working Group in the first phase of the BPP. We are releasing this white paper as a draft discussion piece to engender broader participation and response to the BPP as we move toward the second phase of the project. 


\section{Introduction:}

\section{A. Key Points and Perspective}

The concept of bioavailability is fundamental to risk assessments and remediation decisions and to defining "environmentally acceptable endpoints." At these endpoints, the concentration of contaminants in soils or other media does not present an unacceptable risk to human health and the environment. Bioavailability refers to how chemicals "behave" and their "availability" to interact with living organisms ("bio"). ${ }^{1}$

Bioavailability has significant implications for exposure risks, cleanup goals and costs. It provides an underlying scientific basis to refine national cleanup policy, better inform site-specific remediation decisions, and direct improved science policy. The salient points about bioavailability are:

- The fact that a chemical(s) can be measured/detected in soil is not determinative of its actual availability or associated risk;

- Risk to human health and the environment is tied directly to the bioavailability of a chemical; and

- Chemical concentrations can sometimes be many times above "background" and still be safe and protective of human health and the environment.

As decision-makers become better informed about bioavailability, traditional measures of successful cleanup, based upon minimizing chemical concentrations in soils and sediments, can be refined. ${ }^{2}$

Remediation activities that are more cost-effective can be undertaken while still providing environmental protection. With that in mind, this white paper provides (i) an explanation of the basic nature of bioavailability in soils, (ii) draws parallels to sediments and aqueous media where appropriate, and (iii) places the science in the context of public policy and decision-making for risk assessments and cleanup requirements at contaminated sites.

While the trend toward greater flexibility in our overarching national cleanup policy has quickened since 1990 , the inherently conservative scheme of the 1980 's still predominates. Thus, "default" assumptions (e.g., the amount of chemicals detected equals the amount released, transported, and causing a receptor effect) are generally used in risk assessments.

Similarly, assumed exposure at "worst case" screening levels, like direct "lifetime" human ingestion for 270-365 days per year, has been central to defining protective endpoints. Where there is gross contamination, an apparent imminent threat, and a lack of site-specific data, this approach may be appropriate. But it appears that too often this "one size fits all" approach has led to cleanup decisions that drive remediation to "background" levels or certainly to cleanup requirements in many cases that are beyond what is necessary to be protective. ${ }^{3}$ 
The issue is not about avoiding cleanup of toxic, mobile chemicals; rather it is to understand that in soils, chemicals can be less mobile and less- or non-toxic, and thus, present less risk in many cleanup situations. Information to support this understanding can be acquired and used to make determinations that supplement options for site management.

This paper recommends changing policy to emphasize bioavailability so that cleanup requirements are better aligned with current science and information. In the case of bioavailability, this change takes the form of assuring that information about actual chemical(s) availability, mobility and toxicity at a site is provided to decision-makers. In short, what is needed is uniformity and consistency in the assessment process that reflects actual risks at sites for both ecological and human health protection.

This information is necessary to bridge the gap between what science reveals (e.g., that various mechanisms in the soil can stabilize chemicals at a site, cleanup can be tailored to actual conditions) and what regulations or policy often require (e.g., that chemicals have been detected and the site must be completely excavated/treated).

\section{B. A Tool For Better Decision-Making}

Some state as well as federal-lead sites have begun to incorporate bioavailability into both risk assessment methods and remediation decisions; however, the majority have proceeded from generic criteria and upper bound risk. Recently, EPA models have used a "default" bioavailability assumption of $30 \%$ for lead exposures to children; a low-end range of $20-40 \%$ up to $80 \%$ for arsenic at some sites. This contrasts with the notion of $100 \%$ bioavailability, reflected in analyses at many more sites, where the assumption made is that the concentration of chemical detected defines the risk. But science now supports and identifies the factors appropriate to application of bioavailability at all sites. Thus, an apparent policy issue is the rapidly increasing disparity in the national decision-making apparatus between the definitions for remediation goals, actual versus "worst case" risks, and applicable remedies.

Also illustrative of this uneven policy execution is in-situ bioremediation. This is an alternative often considered to achieve cleanup (even for sites where risks and remedies have been derived from "worst case" assumptions); yet application of bioavailability, involving the exact same scientific principles, to define cleanup requirements seems to occur on an ad hoc basis at best. ${ }^{4}$

A question that arises is that if some states or site managers are applying the concept-collecting bioavailability data, and using that data to define remedy requirements and better inform decision-makers - why not all states and site managers? Indeed, collection and application of site-specific data on chemical release, transport, and receptor effects can contribute not only to better decisions, but also to advancing the scientific knowledge needed to formulate predictive tools and standardized field tests.

Another question that arises is, "Why not just clean up the site and stop the studies and expenditures for site evaluation?" In the context of a genuine desire to complete cleanups in a timely and cost 
effective manner (not to avoid taking action), the answer is that information on chemical availability, mobility and toxicity in soils helps define improved options for what to do, how to do it, and how far to go to achieve environmentally acceptable endpoints.

There are instances where data on bioavailability are collected but not used to inform decision-makers or refine cleanup decisions. Instead, the use of general national criteria and assumptions prevails in cleanup decisions. Although the Risk Assessment Guidance for Superfund (RAGS) and other guidance leave open the possibility of using bioavailability information at sites, a number of hindrances remain. This appears to be attributable to a number of factors, ranging from perceived failure in the delegation of authority to all decision levels to simple uncertainty on the part of site managers to run the "risk" of moving from the conservative posture of using "worst case" assumptions. What seems more likely is inadequate education, communication and information for decision-makers at all levels about what the weight of scientific evidence on bioavailability now tells us, and what to do with the evidence. In any case, policy change to rectify the situation is long overdue. ${ }^{5}$

Because bioavailability data help isolate and explain chemical behavior and broaden, not replace, the options and tools for cleanup at a specific site, protection to environmentally acceptable endpoints can be achieved. Many factors enter into the definition of a protective environmentally acceptable endpoint at a site, including current and reasonably likely future land use, nature and extent of contamination, and risk to human or ecological receptors. Expressed another way, bioavailability serves to explain the dose/receptor response at a site and land use defines the receptor of concern. ${ }^{6}$ Of highest importance is the need to acquire site-specific data, bolstered by an unequivocal policy to do so. In this regard, EPA's guidance on "Monitored Natural Attenuation" provides a boost for broadened site characterization (i.e., intrinsic bioremediation) in cleanup remedies. ${ }^{7}$ 


\section{Snapshot of the Current Risk Paradigm}

To pose a risk, chemical(s) in soil must first be available to a receptor by mobilization and transport, then cause an adverse response due to exposure through various routes such as ingestion of water or soil, inhalation, or dermal contact. This concept is depicted in Figure 1.

Figure 1. Conceptual Risk Paradigm (From reference 18 in Appendix $B$ )

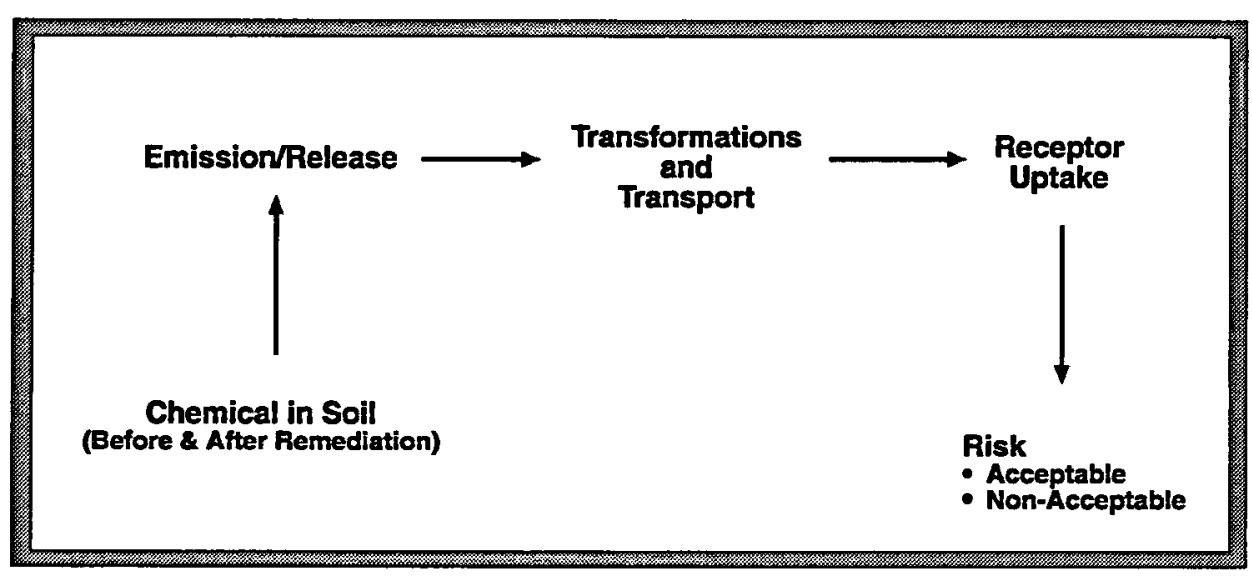

The prevailing application of this paradigm is inherently conservative. The concentration of chemicals detected (i.e., the "total" measured for either metals or organics) is presumed to be released; the presumed toxicity is that of the pure chemical, neither attenuated nor transformed; and it is presumed that the entire concentration reaches a receptor and causes toxicity.

The effect of bioavailability on the conceptual framework of Figure 1 involves basic considerations of physical and chemical reactions that bind chemicals, mechanisms that alter the potential for and rate of release of chemicals, and various assays to assess ecological and toxicological effects.

Availability of a chemical (e.g., for soils or ground water at a given site) is a significant factor affecting the extent to which a chemical, at any concentration, presents an environmental threat. Two points about chemical availability are especially important.

First, under existing conditions a site may reflect a range of situations. At one extreme, the condition may be a recent spill where "fresh" chemicals are more available for leaching (release/mobility), degradation (transformation) and bio-uptake (exposure/receptor). Alternatively, the condition may be one of "aged" chemicals that have been in contact with the soils/sediments for years or decades where the chemicals are, sometimes significantly, less available. The difference is important because in the latter situation, chemicals are held tightly by soil/sediments and there may be little need for remediation. 
Second, over time chemical availability changes and leaching and degradation decline as soluble chemicals are degraded by microorganisms or are bound by chemical mechanisms such as precipitation or irreversible binding to organic matter. Remaining chemicals are adsorbed or bound in the soil matrix, become less mobile, less available and pose a reduced risk to the environment.

In terms of the risk assessment paradigm, chemical availability impacts the rate and amount of chemical release and the immediate effect. From the moment a chemical comes into contact with a soil, a variety of natural physical and chemical processes occur, depending on factors such as soil type, $\mathrm{pH}$, alkalinity, porosity, and temperature, that result in the diffusion and distribution of the chemical onto soil particle surfaces and into soil particle pores. Over time, there is further movement and sequestration of a chemical into soil particle surfaces or further chemical complexing that inhibits the availability to organisms.

In the case of a site with ground water contamination, for example, bioavailability data can help determine if a release of the contaminant is continuing, the extent to which mobility and exposure are changing, and the extent that the receptor effect may differ from the toxicity of pure compound. 


\section{Snapshot of the Current Decision Paradigm.}

The often routinized application of overarching national policy of the last 15 years still prevails. The policy strongly suggests that it is necessary to be consistently conservative between and among all sites to be both "sure" and "safe" in risk assessment and remediation requirements. Nationally-applicable criteria based upon inherently conservative assumptions are used to provide an artificially high margin of safety such that ultimate cleanup decisions would be defensible as "protective." The conservative logic has fostered pressures to "clean up to background" inasmuch as anything less would not "guarantee" permanence. This situation could well be contributing to increased environmental risk nationally because fewer sites can be cleaned up to this extent in the context of finite resources.

Fifteen years ago, when the most fundamental decisions about "environmentally acceptable endpoints" were being made, bioavailability was a less well-known scientific concept, the implications of which were never well-known to senior decision-makers who, nevertheless, were confronting major policies about "how clean is clean."

It seems that over the years the notion of consistency has instilled a "cookbook" approach that has resulted often in adherence to non-binding guidance using conservative assumptions. There is an overlay of "bean-counting" schedules where success is measured by completing steps in a process using generic models and assumptions, not in acquiring site-specific data. These and other factors have fostered a paradox wherein it is acknowledged that bioavailability data would be useful, but take too long to acquire; therefore, sites remain unaddressed, in litigation, "being studied," or "mothballed" for longer than the time needed to acquire data and make better informed decisions.

Change is underway because confidence has increased significantly due to more information. ${ }^{8}$ There has been a dramatic increase in completed research that demonstrates the scientific aspects of "natural attenuation" (i.e., some contaminated sites can recover naturally to protective conditions) which involves the same basic scientific concepts as bioavailability.

For whatever reasons, it appears that many "on scene" project managers are not empowered with this information as guidance and policy do not encourage the use of bioavailability data to make cleanup decisions. Given the growing body of science in this area, there is a significant opportunity to turn this around.

Policies emphasizing "worst sites" and "immediate threats" first have improved the pace and priority of cleanup and corrective action, but the scope of problem definition is still driven by "potential" exposures, concentrations and amounts detected; rather than by information on chemical fate and transport, and the likely effect (i.e. bioavailability). Moreover, even after the "immediate threats" are removed, it is frequently unknown what, if any, further cleanup is/will be necessary - in large part due to a lack of bioavailability data. 
In addition, national policy has focused on future land use for residential purposes, even where industrial development was intended, and bioavailability data needed to make the best decision generally are not sought or available to define zoning requirements, long-term land use options, and site cleanup goals. 


\section{Overview of Scientific Concepts}

The science of bioavailability and the current "weight-of-evidence" derive from a substantial body of research, field studies, and site investigations that encompass a vast array of site characteristics and contaminant problems. The collective information involves the biological, chemical and physical processes which occur in soils and sediments and the behavior of contaminant chemicals undergoing those processes at individual sites. Several compendia reflecting two to three decades of investigation are now available for detailed discussions of virtually all aspects of bioavailability.9

This section presents a brief overview of the fundamental scientific concepts of bioavailability for the general case of soils with a few pertinent points about parallels or differences for groundwater/ sediments as a means to explain "the basics" in a policy discussion.

There are many factors that qualitatively affect a chemical exposed to soils or sediments and that are especially important in quantitative outcomes as well. Empirical studies have established that processes such as soil particle adsorption, degradation by microorganisms, and chemical complexation/sequestration are especially important. Each of these processes is affected by a wide variety of site-specific factors such as the nature of rainfall events, soil type, oxygen concentration, $\mathrm{pH}$, alkalinity and hardness. As noted earlier, in the case of "aged" chemicals, generally encountered in remediations due to past spills or disposal at sites, the soil processes tend to "utilize" easily degradable chemicals and "stabilize" the recalcitrant chemicals within the soil matrix. This results in significantly less bioavailability and therefore reduces the potential effect on a receptor. As depicted in Figure 2, the soil processes can materially affect/attenuate the rate and extent of chemical release, transport, transformation, and toxicity, and thus, have an impact upon risk.

Figure 2. Impact of Availability on Risk Paradigm (From reference 18 in Appendix B)

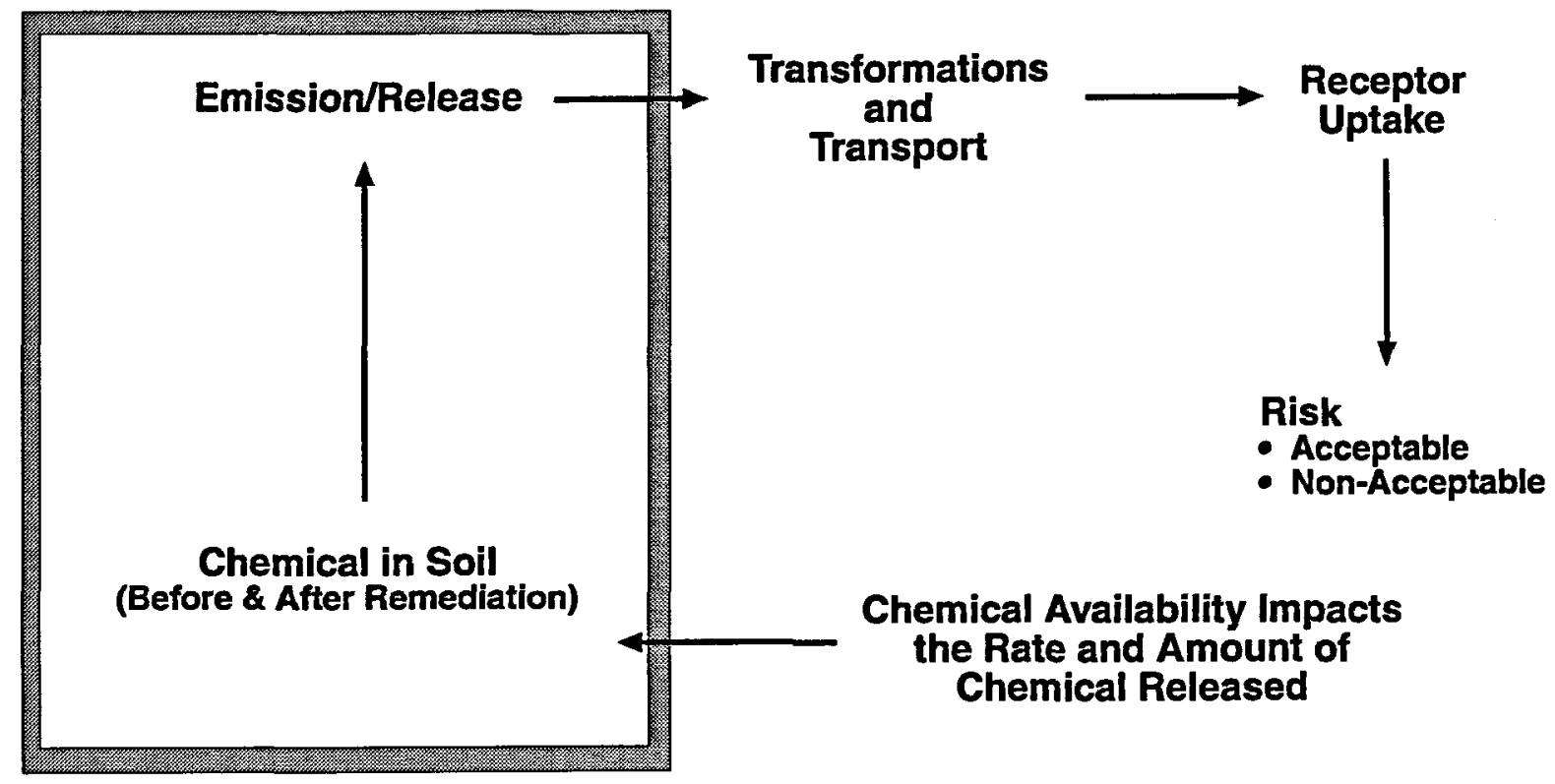




\section{A. General Soils/Organics}

In the general case of soils, a few simplified examples are illustrative of the pertinent scientific principles. Organics such as crude oil or fuel hydrocarbons spilled or disposed on the land initially have high rates of volatilization, leachability into groundwater, and migration within the soil. At high concentrations/high volumes, immediate receptor effects can be quite serious. But a different situation may exist at previously contaminated sites where remediation is contemplated.

Several natural processes occur that destroy or alter the chemicals. The processes begin fairly soon after the original spill or disposal incident and continue over time. These include:

- Volatilization to the atmosphere. This can be rapid at first for many hydrocarbons, but stabilizes and decreases over time as chemicals degrade or become bound in the soil.

- Leaching and migration into soil pore space or groundwater. These also decline as chemicals are degraded/destroyed by microorganisms in soil/water and chemical molecules become dispersed and bound to soil particle surfaces.

- Chemical reactions in soils/water that cause complexation and sequestration of chemicals reduce availability for degradation, leaching. ${ }^{10}$

- Photodegradation contributes to chemical alterations that can reduce the availability and toxicity of many compounds."

Over time, as soils "age" (or following some remediation), the weight-of-evidence shows that a quasi-equilibrium condition is established such that some residual chemical diffusion and release occur and there is some availability for transport. Nevertheless, the processes of degradation, assimilation and sequestration in soils actually "treat" the release or bind the chemical in the pores of individual soil particles so there may be little or no "availability" for adverse receptor effects (Figure 3).

Figure 3. The General Conceptual Interaction of Chemicals and Soils and the Availability of Chemicals in Treated or "Aged" Soils (From reference 18 in Appendix B)
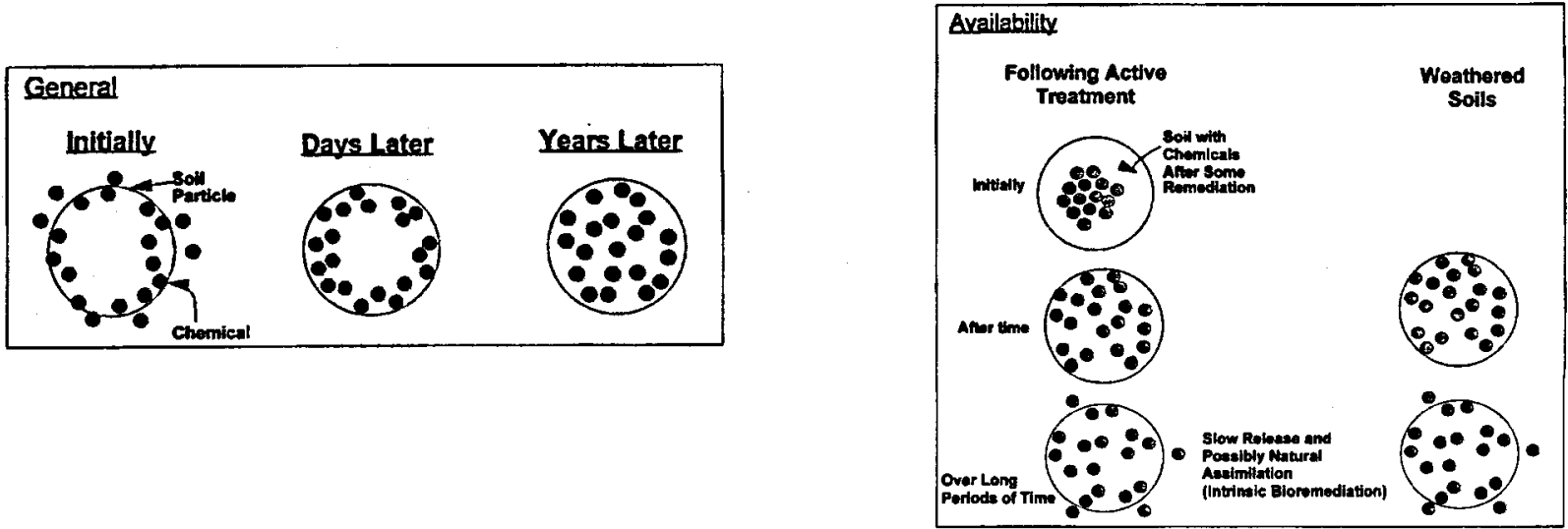
Specific examples from field studies/research investigations of the behavior of organic chemicals demonstrate the significance of bioavailability in its application at sites.

\section{Coal/Oil Gasification Plant Site ${ }^{12}$}

Focused laboratory and site investigations of soils at a coal/oil gasification facility showed that organic hydrocarbons at a former manufactured gas plant were not able to be degraded. Studies revealed that active bacteria present would degrade "fresh" hydrocarbons added to the soil; but not the same hydrocarbons that had been in the soil for many years. In addition, the soil was non-toxic.

\section{Wood-treating site: Creosote and Pentachlorophenol (PCP) ${ }^{13}$}

An engineered soil treatment system that operated for eighteen months at a wood-treating plant that used creosote and PCP was evaluated. Early testing showed that active degradation and chemical sequestration was underway. Two months after the operation ceased, a continuing decline in both total chemical and leachate concentrations was observed. Six years later, tests revealed that both concentrations were approaching zero and that there was no migration of contaminants out of the treatment system (Figure 4). Similar investigations at another wood-treating site showed a decline in chemical concentration from over 8000 parts per million (ppm) to less than $200 \mathrm{ppm}$, and the soil was non-toxic to microorganisms and earthworms after a period of about four and a half years.

Figure 4. TCLP Concentration Achieved for Organic Reduction Hydrocarbons and Pentachloraphenol in Wood Treating Site Soils (From reference 3 in Appendix B)
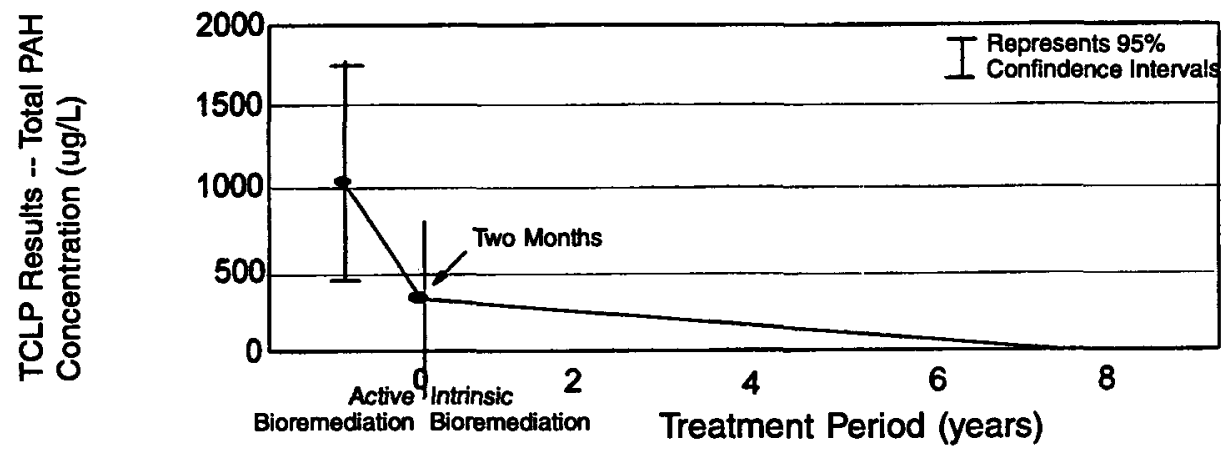

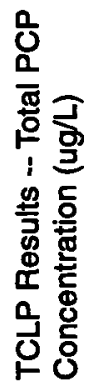

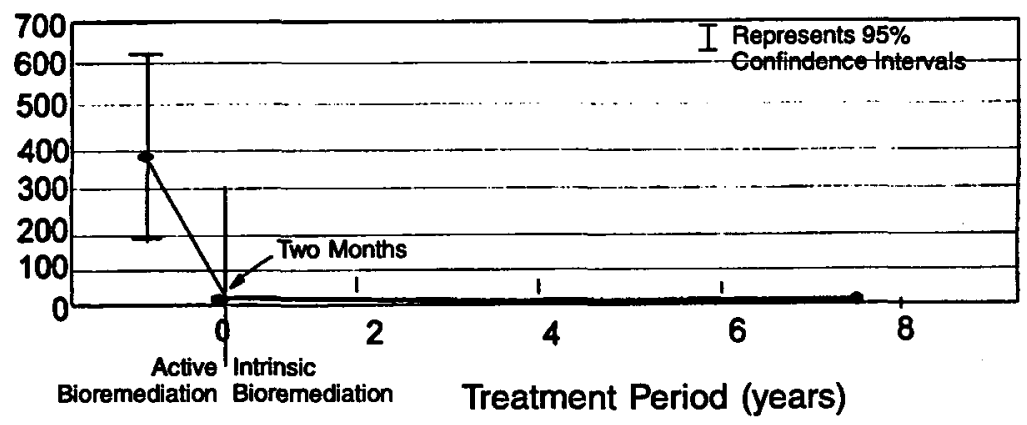




\section{Petroleum Refinery/Oily Waste ${ }^{14}$}

Initial studies of soils contaminated with gasoline, diesel fuel and oil hydrocarbons showed moderate toxicities, but after eight weeks of bioremediation, the hydrocarbon toxicity had reduced to non-toxic levels. On-site monitoring of a plume of groundwater contamination over a six-year period showed reductions of about $90 \%$ in hydrocarbon concentrations and significant reduction in plume size without any engineered intervention to treat the groundwater.

\section{B. General Soils/Metals}

Only a small fraction of metals found in soils are bioavailable; the larger fraction is usually bound with reacting chemicals making the metal less or unavailable for organism uptake. Metals bioavailability is influenced by physical, chemical and biological factors. Metal solubility and availability are especially affected by $\mathrm{pH}$, and metals in soils interact with many different molecules to form insoluble salt precipitates (i.e., form different metal species). Metals also adsorb onto soil particles and interact with a variety of organic compounds to become complexed, sequestered and less available to environmental receptors. Each species of metal formed in soils has its own fate and transport characteristics as well as toxicological action which are not reflected by terms, for example, such as "total mercury."

Except for mercury and selenium, volatilization of metals is not typically encountered. Leaching and migration of metals in soils depends heavily on particle sorption and surface or chemical interactions. Soils themselves are a variety of mineral/metal matrices such as silicates, clays, and metal oxides; and the shear bulk of the minerals in the environment makes them important in stabilizing chemicals that bind with soil particles and become complexed and sequestered.

Chemical interactions such as reduction and precipitation in soils can alter metals to less available forms or species. For example, the toxic and mobile form of chromium is readily and rapidly reduced to the insoluble form of chromium; ${ }^{15}$ phosphates interact with lead to form highly insoluble forms; ${ }^{16}$ and sulfide forms of mercury are highly insoluble and less available. ${ }^{17}$ In each of these cases the metals are materially less available or unavailable to receptor organisms in the environment (Figure 5).

Figure 5. Different Metal Species in Soils Have Different Water Solubility and Different Ingestion Bioavailability (Adapted from reference 19 in Appendix B)

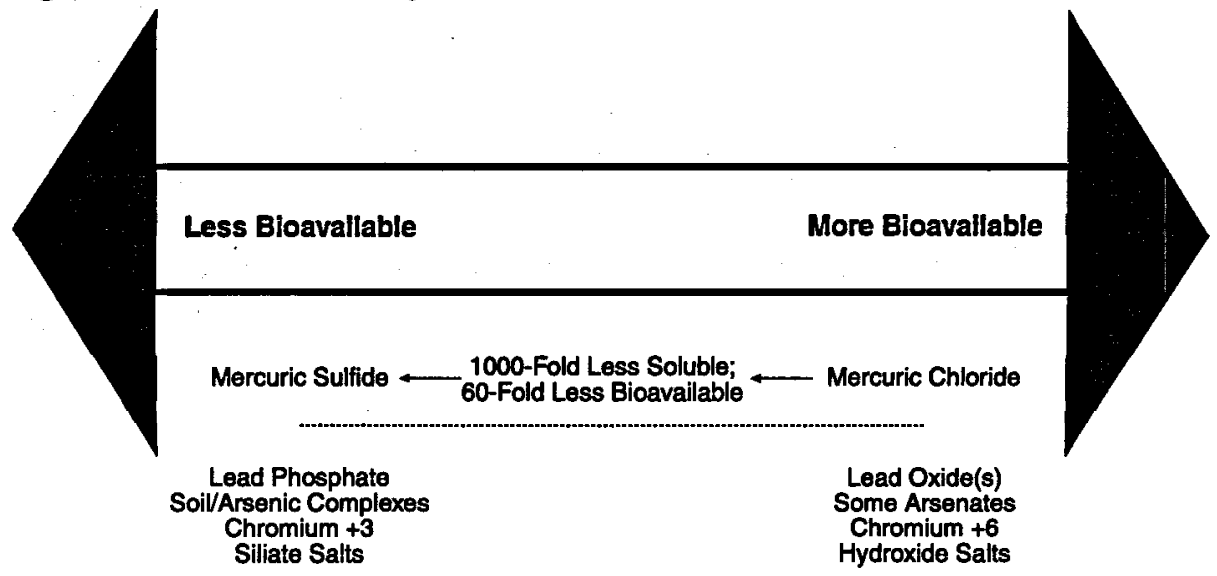


A few specific examples from site investigations serve to demonstrate the application of bioavailability concepts to metals:

\section{Arsenic - bioavailability of soil/dust ingestion $^{18}$}

Ingestion studies of soil and dust near a former smelter site have shown that arsenic complexed with soil can be three to ten times less bioavailable than the soluble form, sodium arsenate, typically measured in standard leach tests. Similar investigations at a chemical manufacturing plant have shown a ten-fold lower solubility and bioavailability of arsenic in soil compared with the soluble forms initially assumed to define the health risks at the site.

\section{$\underline{\text { Lead }}$ - soil/dust ingestion $^{18}$}

Lead contamination has been investigated in a wide variety of settings. Blood lead tests in children at a former mining and smelter site showed lead levels at or below those of the general population even though measured soil and dust lead concentrations ranged from 1,000 to $3,000 \mathrm{ppm}$. Similar results have been encountered at other sites. Lead in soils, in the form of various lead phosphate salts, is orders of magnitude less soluble and $50-100 \%$ less bioavailable than lead acetate, the compound measured in standard leach tests.

\section{Cadmium - plant uptake/ingestion ${ }^{19}$}

Cadmium is readily complexed in soils. Except in cases of gross cadmium contamination, like paint pigments or nickel-cadmium batteries, most situations of cadmium contamination are associated with zinc mine or smelter operations because cadmium is geochemically associated with zinc in ore bodies. For normal soils a zinc/cadmium ratio of about 100 exists and under these conditions there are severe limitations on plant uptake and animal transfer of cadmium.

\section{B. General Sediments/Organics and Metals}

It is appropriate to briefly mention sediments which represent a special case of the bioavailability concepts outlined for soils. By their very nature sediments primarily exist in or under water in a fully saturated environment. Sediments are soil/mineral matrices and, like soils, basic natural process concepts apply. Many differences from unsaturated/upland soils arise, however, because there is less oxygen, different species of microorganisms, typically higher organic matter content, and constant interaction between water and sediment particles.

Wetlands, a combination of exposed soils and submerged sediments, represent a special case of a fragile environment that nonetheless have been found to stabilize chemicals and attenuate pollution dramatically. In the context of remediation of sediments, proper characterization of the same mechanisms otherwise applicable to soils will similarly provide the data to define the risks and cleanup requirements. For contaminated sediment sites, some points emerge to demonstrate the implications of bioavailability. 
- Chemical complexation, particle binding, and the activity of microorganisms are strongly influenced by the presence of iron, sulfides, and manganese in the sediment and water. Bacteria produce sulfide in the low-oxygen sediments, causing sulfide salts of many metals (mercury, copper, cadmium, zinc) to precipitate and exhibit low bioavailability.

- Evidence suggests that organics and metals will stabilize in undisturbed sediments and are unavailable to receptors.

- Leaching and migration of chemicals are primarily at the sediment-water interface and declines over time.

- There are lower levels of mobility and toxicity in sediments in areas of high water hardness compared with areas of soft water.

- Some chemicals, like some forms of PCBs, are more likely dechlorinated in sediments than in soils; hydrocarbons may be less degraded in low-oxygen sediments than in soils. 


\section{Application/Implication of Bioavailability to Environmental Cleanup Settings.}

Investigations show that over time (in soils) chemical availability is reduced, resulting in reduced exposure and risk to human and environmental receptors; that the reduced availability can be measured; and that these measures can be used to define approaches to site management. In making site management decisions, the use of bioavailability information to define environmentally acceptable endpoints helps broaden site investigations and the range of cost effective approaches that are protective of human health and the environment.

"Brownfields" and corrective action activities at operating facilities typify the situation encountered at numerous historically contaminated sites at industrial, DOE, and military facilities where the concepts of bioavailability and the implications for decision-making and cost are brought together.

Reasonably likely future land use dictates the exposure scenario for which site specific availability information is required. "Brownfields" and corrective action sites can present a future potential human health risk/exposure due to groundwater ingestion and possible dust and soil ingestion. However, likely future land uses at many sites present limited or no human health implications. Within this range of possibilities, bioavailability data help to define implications and options for prospective land use as well.

Generic approaches at such sites are easily applied and can be imposed at sites with similar compounds, but may not consider availability and toxicity of chemicals in soils; thus, systematically overestimating risk/effects and cleanup requirements. Site-specific alternatives require a methodology to identify availability and toxicity, and to quantify limitations of the studies. The schematic shown in Figure 6 ties together the points of this paper and portrays a methodology for estimating risk from chemicals in soil. ${ }^{21}$

Figure 6. Components for Estimating Risk from Soil Contaminants (From reference 3 in Appendix B)

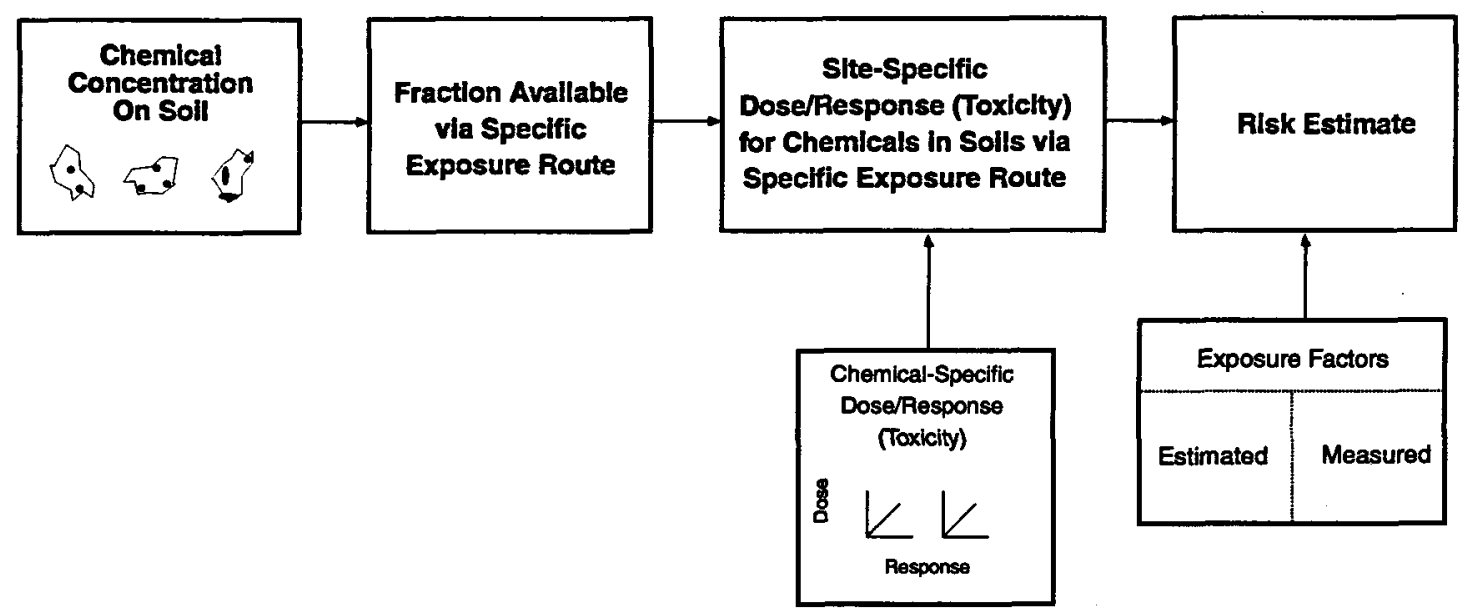


For a site, chemical availability data can address questions such as:

- To what degree are chemicals in soil toxic to terrestrial organisms?

- To what extent are chemicals in soil available and toxic to plants?

- Will chemicals in soil or sediment be released, and to what extent will they cause an adverse effect/risk in groundwater or surface water? (e.g., result in exposure and toxicity to aquatic organisms)

For human exposure these same inquiries can be made to assess the availability and toxicity of chemicals in soils that may adhere to skin, be incidentally ingested, or be inhaled. Answers provide useful data to assure risk is better understood and cost-effective remedies are protective of human health and the environment.

\section{A. Synopsis of Illustrative Case Study}

In September, 1996, EPA announced the final remedy decision for the Lower East Fork Poplar Creek site at the DOE complex in Oak Ridge, Tennessee. The remedy decision was the culmination of a multi-year investigation by DOE, EPA, the Tennessee DEC and local citizens and provides a vivid example of the importance of acquiring the data to assure well-informed (not presumptive) decisions about remediation requirements that assure protection of human health and the environment.

The site involved mercury contamination of some 14.5 miles of watershed covering about 650 acres, much of it in native forest. Bioavailability was brought to bear as part of the scientific basis for the nature and extent of the final cleanup requirement.

The original 1986 EPA cleanup goal was 10 parts of mercury per million parts of soil (ppm). The goal derived from a "worst case" risk assessment using methyl mercury toxicity and based upon an assumed exposure scenario of residential development, soil and groundwater ingestion by children, and "total mercury" concentrations measured around the site. ${ }^{22}$ These "totals" analyses showed high levels of mercury that ranged from $15-2600 \mathrm{ppm}$. The estimate to excavate/clean up such an extensive area to these low levels was $\$ 1.2$ billion.

Subsequently, the "worst case" exposure assumptions were modified to focus on ingestion exposure and a revised clean up goal of $50 \mathrm{ppm}$ was defined. For this revision, bioavailability was assumed at $100 \%$ for soil ingestion by children and the form of mercury was mercuric chloride, a very soluble salt that is $10-100$ times less toxic than methyl (organic) mercury.

The revised cleanup goal still involved excavation of 50,000 cubic yards of soil and treatment by desorption of mercury from the soil at a cost of $\$ 168$ million. Additional contaminant bioavailability testing by DOE at the site showed that due to soil mineralogy, the form of mercury in the soils was partly elemental mercury but mostly a sulfide salt that ingestion studies revealed to be 1000 -fold less soluble than mercuric chloride. 
Detailed animal uptake and simulated (human) digestion studies showed an upper bound of $30 \%$ exposure instead of $100 \%$. These bioavailability data and other information provided for a fully informed local public as well as state and federal officials and broadened the options for cleanup and habitat protection. The result was a cleanup level of $400 \mathrm{ppm}$ and a remedy that involves excavation and secure landfill disposal of 28,000 cubic yards of soil, replacement of excavated material, and leaving a large tract of wildlife habitat undisturbed. The cost of the final remedy is estimated to be $\$ 8.0$ million; thus, avoiding over $\$ 1.1$ billion in initial estimates and saving $\$ 160.0$ million in site remediation costs. 


\section{Conclusions and Recommendations:}

As decision-makers become far better informed about bioavailability and associated scientific concepts, traditional measures of success in remediation based on reducing the concentration of chemicals in soils can be refined. Specific cleanup requirements can be tempered in both time and degree. This can accelerate cleanup activities and establish a more efficient deployment of the public and private resources involved.

As an outgrowth of the discussions, meetings, and literature reviews used as a basis of this paper, some general findings and suggested actions can be identified.

\section{A. Findings:}

1. The weight-of-evidence from scientific investigations shows that over time mechanisms in soils can complex, sequester, or otherwise "treat" contaminants such that availability, mobility, and/or toxicity (i.e., the "bioavailability") can be reduced and may be eliminated.

2. Much of the policy and guidance at the federal level provides the opportunity to use bioavailability information to define risk and cleanup decisions. However, the "bar is set too high" due to a lack of communication, education and policy approval for many site managers and decision officials to move away from the far simpler (if less scientifically appropriate) conservative models and "default" assumptions that can overstate risk and restrict remediation options.

3. Emerging policy and practice changes, particularly in some states and at some sites, have begun to better target the use of bioavailability information in risk assessments and risk management decisions; but there is no significant consensus as to whether or how to do so at all sites.

4. The science is now sufficiently compelling to demonstrate the possible roles and implications for bioavailability information in defining risks and remediation options.

\section{B. Action Steps:}

1. Incorporate the concept of bioavailability explicitly into the national cleanup policy framework; thus, recognizing that chemical detectability is not tantamount to availability, exposure, or toxicity.

2. Integrate acquisition of chemical bioavailability data into all site assessments to enhance knowledge and improve decisions about the nature of risks and degree of remediation necessary to be protective of health and the environment. 
3. Incorporate bioavailability concepts into risk characterization and cleanup remedy information provided to decision-makers (especially at the state and local/site level) to both better inform the public and enhance understanding of the implications of future land use decisions.

\section{Scientific Needs:}

1. Take actions to achieve agreement among stakeholders to define the typical battery of current bioavailability tests and procedures to be used at sites.

2. Direct activities to develop simple, rapid field methods to apply in site assessments.

3. Target research and studies to determine specific mechanisms that control bioavailability and develop predictive tools to streamline the assessment process.

4. Assure acquisition of data on chemical availability, mobility, and toxicity in any future long-term field research studies to continue building upon the existing weight-of-evidence information. 


\section{Endnotes}

1 Some in the scientific community use the term "bioavailability" more specifically to describe the degree of organism impact, and "fate and transport" to describe the availability mechanisms; others use the term "bioaccessability" or "absolute bioavailability."

2 The bioavailability concepts apply in programs implemented under a variety of federal statutes (and state counterparts) including CERCLA, RCRA, TSCA, CWA and others.

3 A series of guidance documents issued by EPA (Risk Assessment Guidance for Superfund, "RAGS,") between 1989-1991 provide discussion of the utility of site-specific information to define remediation goals, risks, and remedy options. Portions of the RAGS appear to provide ample opportunity to permit the use of bioavailability in the cleanup decision process. For example, the Environmental Evaluation Manual provides a brief summary of physical/chemical aspects of media (including soils) stating that a variety of environmental variables interact with contaminants and make the contaminants more or less toxic or available in the environment and organisms more or less tolerant of the chemical.

4 See J.L. Sims et al., In Situ Bioremediation of Contaminated Unsaturated Subsurface Soils (EPA 540/ 593/501, Washington, DC: 1993) for an informative discussion of bioremediation as a remedy in soils cleanup in the EPA "Engineering Issues" series of publications.

5 One noteworthy example of change is the Texas Risk Reduction Program (TRRP) of the Texas Natural Resource Conservation Commission that specifically incorporates bioavailability as a possible means to determine site-specific cleanup criteria.

6 Assumptions about "reasonable" future land use are integral to the risk assessment/remedy selection process; they can be the single most important factor in ultimate remedy requirements. In this regard, bioavailability data provided early in the planning process can help better define the environmental implications of a range of land use possibilities, e.g., at a military site potentially released for alternative uses.

7 See United States, Environmental Protection Agency, "Use of Monitored Natural Attenuation at Superfund, RCRA Corrective Action, and Underground Storage Tank Sites," OSWER Dir. 9200.4-7 (Washington: EPA, 1997). This directive, released November 1997, allows for the collection and consideration of expanded site data. In addition to monitoring, it calls for comprehensive site characterization, risk assessment and/or control measures when implementing natural attenuation as a remedy or a component of a remedy.

8 For example, EPA has specifically identified bioavailability as one key subject area currently being assessed for incorporation into broader guidance associated with lead contamination at sites. "Administrative Reform for Lead Risk Assessments" (EPA 540/F-97015, Washington, DC: 1996)

9 Jerry L. Hamelink et al., eds., Bioavailability: Physical, Chemical, and Biological Interactions, Proc. of Thirteenth Pellston Workshop (SETAC Special Publ. Ser. Ann Arbor: Lewis Publishers, 1994); S.E. Hrudey, W. Chen, and C. G. Rousseaux, Bioavailability in Environmental Health Risk Assessment (Ann Arbor. Lewis Publishers, 1995); David G. Linz and David Nakles, eds., Environmentally Acceptable Endpoints in Soil (Annapolis: American Academy of Environmental Engineers, 1997).

10 Martin Alexander, "How Toxic are Toxic Chemicals in Soil?" Environmental Science and Technology 29 (1995): 2713-2717.

11 Hamelink et al.; Linz and Nakles. 
Linz and Nakles.

13 Linz and Nakles; J. R. Smith, et al., "Definition of Bioremediation Endpoints for PAH Contaminate \& Soils Using a Risk-Based Approach," Presented at the Ninth Annual Conference on Contaminated Soils, Univ. of Massachusetts at Amherst, October 18-20, 1994.

14 Linz and Nakles; Electric Power Research Institute, "Characterization and Monitoring Before and After Source Removal at a Former Manufacture Gas Plant Disposal Site,” EPRI TR-105921 (Watertown, MA. 1996)

15 Rufus L. Chaney, James A. Ryan, and Sally L. Brown, Development of the US-EPA Limits for Chromium in Land-Applied Biosolids and Applicability of these Limits to Tannery By-Product Derived Fertilizers and Other CR-Rich Soil Amendments. In Proc. Chromium Environmental Issues Workshop ( San Minianto, Italy 1996).

16 J.D. Cotter-Howells et al., "Identification of Pyromorphite in Mine-Waste Contaminated Soils by ATEM and EXAFS," European Journal of Soil Science, 45 (1994): 393-402; G.B. Freeman et al., "Relative Bioavailability of Lead from Mining Waste Soil in Rats," Fundamental and Applied Toxicology 19 (1992) 388-398; Christopher M. Sellstone, et al., "Reduction of Risk Through In Situ Amendment of Leaded Soils," Presented at the 11th Annual Congerence on Contaminated Soils (University of Massachusetts at Amherst 1996).

17 Andy Davis, Nicholas S. Bloom, and Shane Que Hee, "The Environmental Geochemistry and Bioaccessibility of Mercury in Soil and Sediment: A Review.” Risk Analysis, (1996) Paper No. 96-120.

18 G.B. Freeman et al, "Bioavailability of Arsenic in Soil and House Dust Impacted by Smelter Activities Following Oral Administration in Cynomolgus Monkeys," Fundamental and Applied Toxicology 28 (1995): 215-222.

19 Cotter-Howells, et al. 393-402; James B. Heneghan et al., "Composting Biosolids Reduced Soil Lead (Pb) Bioavailability in Rat Feeding Studies” (Composting Council Annual Meeting, Washington, DC. 1994)

20 Rufus L. Chaney et al., "Phyto-Availability and Bio-Availability in Risk Assessment for CD in Agricultural Environment," In Proc. of OECD Cadmium Workshop (Stockholm, Sweden 1995)

21 Linz and Nakles at 400 .

22 Chemical speciation studies are paramount in dealing with metals contamination. Forms of mercury such as methyl (organic) mercury are much more soluble and toxic than other forms and can occur in reactions in the soil; although, soils rich in sulfide minerals tend to stabilize and sequester much of the mercury in generally insoluble forms. This is similar to the point noted earlier in this discussion about phosphate forms of lead and zinc inhibition of cadmium uptake. 


\section{APPENDIX A}

\section{Bioavailability Policy Project Members}

NEPI wants to thank the Director of the Bioavailability Policy Project, Don Clay, President, Don Clay Associates, and the other participants of this project who graciously gave so much of their time and expertise to the project.

Dr. Daniel Abramowicz, Manager, Environmental Laboratory, Corporate Research and Development for General Electric.

Dr. William J. Adams, Director, Environmental Science Program, Kennecott Utah Copper.

Dr. Martin Alexander, Liberty Hyde Bailey Professor, Department of Soil Crop and Atmospheric Sciences, Cornell University.

Ms. Robin Anderson, Environmental Scientist, Office of Emergency and Remedial Response, US EPA.

Mr. Bruce Bauman, Research Program Coordinator for Soil, Ground, Water, Health \& Environmental Sciences, American Petroleum Institute.

Mr. Nelson Beyer, Research Zoologist, Department of Interior, Patuxent Wildlife Research Center.

Dr. Richard F. Bopp, Associate Professor, Dept. of Earth and Environmental Sciences, Rensselaer Polytechnic Institute.

Dr. Michelle Broido, Acting Director, Environmental Science, US Dept. of Energy.

Dr. Jennifer Brower, Post Doctoral Fellow, Naval Research Laboratory.

Dr. James Bus, Technical Director, Health \& Environmental Science, The Dow Chemical Company.

Dr. Rufus Chaney, Research Agronomist, Env-Chem Lab, USDA-ARS.

Mr. Don Clay (Project Director), President, Don Clay Associates and former Assistant Administrator for Solid Waste; Assistant Administrator for Pesticides and Toxic Substances.

Mr. Geoffrey D. Cullison, Envinonmental Engineer, Office of the Chief of Naval Operations, Environmental Protection, Safety, and Occupational Health.

Ms. Kimberly L. Davis, Assistant Director, Waste Management Research and Education at the University of Tennessee.

Dr. John Davis, Research Leader, Health \& Environmental Sciences, The Dow Chemical Company.

Mr. Jeff Denit, Vice President and Technical Director, Don Clay Associates.

Ms. Kate Devine, President, Devo Enterprises, Inc.

Dr. Stephen Ells, Senior Environmental Scientist, US EPA.

Mr. Eugene Ervin, Corporate Director, Environmental Health \& Safety, Air Products and Chemicals, Inc.

Dr. Alan R. Goldhammer, Director, Technical Affairs, Biotechnology Industry Organization.

Dr. Kenneth Green, Senior Policy Analyst, Reason Public Policy Institute. 
Mr. Simeon Hahn, Biologist, Northern Division, Naval Facilities Engineering Command.

Dr. Jack Hanley, Environmental Health Scientist, ATSDR.

Mr. Gary Heinz, Research Biologist, Department of Interior, Patuxent Wildlife Research Center.

Mr. Pat Keaney, Associate, Blasland, Bouck \& Lee

Dr. Ronald Kendall, Department Director, Environmental Toxicology, The Institute of Wildlife and Environmental Toxicology at Clemson University.

Dr. Nick Kolak, Research Scientist, New York State Department of Environmental Conservation.

Dr. Walt Kovalick, Director, Technology Innovation Office, Office of Solid Waste and Emergency Response, U.S. EPA.

Dr. Bruce Krewinghaus, Manager, Environmental Technology, Shell Development Company.

Mr. Tim Larson, Professional Engineer, Florida State Department of Environmental Protection.

Dr. Maureen E. Leavitt, Bioremediation Specialist, Strategic Applications International, Corporation (SAIC).

Mr. David Linz, President, LinzTech, Inc.

Dr. Raymond C. Loehr, Chairman, Environmental Solutions Program, University of Texas at Austin.

Mr. Todd A. Margrave, Program Manager, Environmental Technology Transfer, Naval Facilities Engineering Command.

Dr. Terry McIntyre, Head, Biotechnology Advancement Program, Environmental Protection Service.

Dr. Frank Mondello, Microbiologist, R\&D Center, General Electric.

Dr. David Nakles, Principal, ReTec; Adjunct Professor, Civil \& Environmental Engineering, Carnegie-Mellon University.

Dr. Roger E. Nelson, Vice President of Extermal Affairs, BHP Minerals.

Dr. Edward F. Neuhauser, Senior Research Specialist, Research and Development, Niagara Mohawk Power.

Mr. Richard Newsome, Assistant for Environmental Restoration, Office of the Secretary of the Army for Installation, Logistics and Environment, Department of Defense.

Ms. Joanne Otani, Senior Associate Health Scientist, ChemRisk/McLaren Hart

Mr. David G. Page, Program Manager, Environmental Management Oak Ridge, US Dept. of Energy; Fellow, Hon. Zach Wamp's Office.

Ms. Tonie Patterson, Arkansas Remediation Manager, ALCOA.

Dr. Frederic K. Pfaender, Director, Carolina Federation of Environmental Programs, University of North Carolina at Chapel Hill.

Ms. Barbara Price, Vice President, Health and Environmental Safety, Philips Petroleum Company. 
Mr. Michael Rodemeyer, Chief Minority Council, House Science Committee.

Dr. Thomas Roose, General Manager, Environmental and Safety Business Units, Gas Research Institute.

Dr. Stephen Safe, Professor of Toxicology, Cöllege of Veterinary Medicine, Texas A \& M University.

Dr. Ann Saterbak, Associate Research Engineer, Shell Development Company.

Dr. Gary S. Sayler, Professor, Microbiology \& Ecology, Director of Center for Biotechnology, University of Tennessee at the Knoxville.

Dr. Sunil Shah, Remedial Technology Manager, Union Carbide.

Dr. Jodi R. Shann, Associate Professor, Department of Biological Sciences, University of Cincinnati.

Ms. Wendy Sherman, Manager, Superfund Issues, Chemical Manufacturers Association.

Dr. David Sherr, School of Public Health, Boston University.

Mr. Mark Smith, Assistant Counsel, Unocal.

Dr. John R. Smith, Director, Environmental Remediation Technology, Aluminum Company of America.

Ms. Lynne Stauss, Naval Facilities Engineering Service Center.

Dr. William A. Suk, Chief, Chemical Exposures and Molecular Biology, National Institute of Environmental Health Sciences.

Dr. Ralph Turner, Frontier Geosciences.

Dr. Scott Weber, Executive Director, New York State Center for Hazardous Waste Management.

Dr. Jeanne Willson, Senior Toxicologist, Kleinfelder.

Mr. Paul Yaroschak, Director, Environmental Compliance \& Restoration, Office of Assistant Secretary of the Navy.

Dr. Margaret Zak, Environmental Project Engineer, US Steel.

Dr. Larry Zaragoza, HSED Special Assistant, U.S. EPA. 


\section{APPENDIX B}

\section{Selected References}

\section{Compendia on Bioavailability}

1. Hamelink, Jerry L., et al., eds. Bioavailability: Physical. Chemical, and Biological Interactions. Proc. of Thirteenth Pellston Workshop, August 17-22, 1992, Pellston, MI. SETAC Special Publ. Ser. Ann Arbor: Lewis Publishers, 1994.

2. Hrudey, S.E., W. Chen, and C. G. Rousseaux. Bioavailability in Environmental Health Risk Assessment. Ann Arbor: Lewis Publishers, 1995.

3. Linz, David G., and David Nakles, eds. Environmentally Acceptable Endpoints in Soil. Annapolis: American Academy of Environmental Engineers, 1997.

\section{Books, Articles \& Reports}

4. Adams, William J. "Bioavailability of Neutral Lipophilic Organic Chemicals Contained on Sediments: A Review." Fate and Effects of Sediment-Bound Chemicals in Aquatic Systems. Eds. Kenneth L. Dickson, Alan W. Maki, and William A. Brungs. SETAC Special Publ. Ser. __. Pergamon Press, _. 219-244.

5. Alexander, Martin. "How Toxic are Toxic Chemicals in Soil?" Environmental Science and Technology 29 (1995): 2713-2717.

6. Barnett, M.O. and R.R. Turner. Bioavailability of Mencury in East Fork Poplar Creek Soils. Oak Ridge: Oak Ridge National Laboratory, 1995.

7. Beck, Barbara D., et al. "Risk Assessment." Metal Toxicology. Eds. Robert A Goyer, Curtis D. Klaassen, and Michael P. Waalkes. San Diego: Academic Press, 1995. 141-185.

8. Bergstrom, Paul D., et al. "The Use of Site-Specific Studies to Assess Arsenic Health Risk at a Superfund Site." Arsenic: Exposure and Health. Eds. Willard R. Chappell, Charles O. Abernathy, and C. Richard Cothern. Denver: ARCO, 1993: 239-249.

9. Chaney, R.L., et al. "Phyto-Availability and Bio-Availability in Risk Assessment for CD in Agricultural Environment." In Proc. of OECD Cadmium Workshop, Oct. 15-22, 1995, Stockholm, Sweden.

10. Chaney, Rufus L. and James A. Ryan. Risk Based Standards for Arsenic, Lead, Cadmium in Urban Soils. Frankfurt/Main: DECHEMA, 1994.

11. Chaney, Rufus L., James A. Ryan, and Sally L. Brown. Development of the US-EPA Limits for Chromium in Land-Applied Biosolids and Applicability of These Limits to Tannery By-Product Derived Fertilizers and Other CR-Rich Soil Amendments. In Proc. Chromium Environmental Issues Workshop, April 12-13, 1996, San Minianto, Italy.

12. Chappell, W.R., et al. "Findings of the Technical Advisory Committee for the Smuggler Mountain Superfund Site." Hazardous Waste and Public Heath: Intemational Congress on the Health Effects of Hazardous Waste. Princeton: Princeton Scientific Publishing Co. (1994): 127-133.

13. Cotter-Howells, J.D., et al. "Identification of Pyromorphite in Mine-Waste Contaminated Soils by ATEM and XAFS." European Journal of Soil Science, 45 (1994): 393-402. 
14. Davis, Andy, Nicholas S. Bloom, and Shane Que Hee. "The Environmental Geochemistry and Bioaccessibility of Mercury in Soil and Sediment: A Review." Risk Analysis, 1996. Paper No. 96-120.

15. Freeman, G.B., et al. "Relative Bioaváilability of Lead from Mining Waste Soil in Rats." Fundamental and Applied Toxicology 19 (1992); 388-398.

16. Freeman, G.B., et al, "Bioavailability of Arsenic in Soil and House Dust Impacted by Smelter Activities Following Oral Administration in Cynomolgus Monkeys." Fundamental and Applied Toxicology 28 (1995): 215-222.

17. Heneghan, James B., et al. "Composting Biosolids Reduced Soil Lead (Pb) Bioavailability in Rat Feeding Studies." Composting Council Annual Meeting, November 16-18, 1994, Washington, DC.

18. Loehr, Raymond C. The Environmental Impact of Soil Contamination: Bioavailability, Risk Assessment and Policy Implication. Reason Foundation/National Environmental Policy Institute Policy Study No. 211. Los Angeles: 1996.

19. Pastorok, R.A., et al. "Constraints on the Bioavailability of Trace Elements to Terrestrial Fauna at Mining and Smelting Sites." PTI Environmental Services. Poster Presented at 19th Annual Meeting of the Society of Environmental Toxicology and Chemistry, Vancouver, BC, November 5-9, 1995.

20. Ruby, Michael V., Andy Davis, and Andrew Nicholson. "In Situ Formation of Lead Phosphates in Soils as a Method to Immobilize Lead." Environmental Science and Technology 28.4 (1994): 646-654.

21. Schoof, R.A. and G.B. Freeman. "Oral Bioavailability of Lead and Cadmium in Soil from a Smelter Site." PTI Environmental Services and Battell. Poster presented at the Seventh International Congress of Toxicology, Seattle, Washington, July 3-6, 1995.

22. Sellstone, Chrisotpher M., et al. "Reduction of Risk Through In Situ Amendment of Leaded Soils." Presented at the 11th Annual Congerence on Contaminated Soils, University of Massachusetts at Amherst, October 21-24, 1996.

23. Sims, J.L. et al. In Situ Bioremediation of Contaminated Unsaturated Subsurface Soils. U.S. EPA, ORD EPA 540/ 5-93/501, Washington, DC: 1993.

24. Smith, H.S., et al. "Site-Specific Approach to the Development of Risk-Based Cleanup Levels for Organic Mercury in Soils." PTI Environmental Services, Bellevue, Washington. 1996.

25. Smith, J.R., et al. "Definition of Biodegradation Endpoints for PAH Contaminated Soils Using a Risk-Based Approach." In Proc. 9th Conference on Contaminated Soils, 1994, Amherst, MA. 


\section{APPENDIX C}

\section{Additional References}

1. Abdel-Mageed, Asim B. and Frederick W. Oehme. "A Review of the Biochemical Roles, Toxicity and Interactions of Zinc, Copper and Iron: I. Zinc." Veterinary and Human Toxicology 32.1 (1990): 34-39.

2. Barnett, M.O., et al. "Characterization of Mercury Species in Contaminated Foodplain Soils." Water. Air,and Soil Pollution 80 (1995): 1105-1108.

3. Bencko, V. "Nickel: A Review of Its Occupational and Environmental Toxicology." Journal of Hygiene, Epidemiology, Microbiology and Immunology 27.2 (1983): 237-247.

4. Bencko, V. and M. Cikrt. "Manganese: A Review of Occupational and Environmental Toxicology." Joumal of Hygiene. Epidemiology. Microbiology and Immunology 28.2 (1984): 139-148.

5. Berkowitz, Joan B. “Contaminated Site Cleanup Market." Waste Age (1996): 59-66.

6. Berti, William R., Scott D. Cunningham, and Lee W. Jacobs. "Sequential Chemical Extraction of Trace Elements: Development and Use in Remediating Contaminated Soils." In Proc of the Third International Conference on the Biogeochemistry of Trace Elements, Paris, France, May 15-19, 1995.

7. Bhattacharya, Sanjoy K., Robert E. Leslie, and Richard L. Madura. "Effects of Bioavailable Cadmium on Anaerobic Systems." Water Environment Research 67.7 (1995): 1092-1094.

8. Bitton, G., K. Jung, and B. Koopman. "Evaluation of a Microplate Assay for Heavy Metal Toxicity." Archives of Environmental Contamination and Toxicology 27 (1994): 25-28.

9. Blumenthal, Samuel, et al. "Comparative Effects of $\mathrm{Cd}^{(2+)}$ and Cd Metallothionein on Cultured Kidney Tubule Cells." Toxicology and Applied Pharmacology 136 (1996): 220-228.

10. Breault, Robert F. et al. "Copper Speciation and Binding by Organic Matter in Copper-Contaminated Streamwater." Environmental Science \& Technology 30.12 (1996) 3477-3486.

11. Brown, Sally L., et al. "Relative Uptake of Cadmium by Garden Vegetables and Fruits Grown on Long-Term Biosolid-Amended Soils." Environmental Science \& Technology 30.12 (1996) 3508-3511.

12. Calabrese, Edward J. "Toxicological Consequences of Multiple Chemical Interactions: A Primer." Toxicology 105 (1995): 121-135.

13. Chaney, Rufus L., James A. Ryan and George A. O'Connor. "Organic Contaminants in Municipal Biosolids: Risk Assessment, Quantitative Pathways Analysis, and Current Research Priorities." In Proc. of the International Symposium on Organic Contaminants in Sewage Sludge, May 16, 1995, Lancaster, UK.

14. Chaney, Rufus L. 'Food Chain Impact.” Biocycle 31 (1990): 68-73.

15. Chaney, Rufus L. "Twenty Years of Land Application Research, Part I." Biocycle 31.9 (1990): 55-59.

16. Chlopecka, Anna and Domy C. Adriano. "Mimicked In-Situ Stabilization of Metals in a Cropped Soil: Bioavailability and Chemical Form of Zinc.” Environmental Science \& Technology 30.11 (1996): 3294-3303.

17. Douglass, David P., et al., eds. Hazardous Waste News 18.45 (1996): 357-364. 
18. Dragonuk, M.B., W.R. Fehr, and H.J. Jessen. "Nutrient-Solution Techniques for Evaluation of Iron Efficiency of Soybean." Journal of Plant Nutrition 12.7 (1989): 871-880.

19. Driver, Jeffrey H., James J. Konz, and Gary K. Whitmyre. "Soil Adherence to Human Skin." Environmental Contamination and Toxicology 43 (1989): 814-820.

20. Fisher, Nicholas S., et al. "Accumulation and Retention of Metals in Mussels from Food and Water: A Comparison Under Field and Laboratory Conditions." Environmental Science \& Technology 30.11 (1996): 3232-3242.

21. Grandjean, Philippe, et al. "Biomarkers in Environmental Toxicology: State of the Art." Clinical Chemistry 41.12 (1995): 1902-1904.

22. Guo, Tai Liang, Stanley P. Mudzinski, and David A. Lawrence. "The Heavy Metal Lead Modulates the Expression of Both TNF- and TNF- Receptors in Lipopolysaccharide-Activated Human Peripheral Blood Mononuclear Cells." Journal of Leukocyte Biology 59 (1996): 932-939.

23. Heo, Yong, Patrick J. Parsons, and David A. Lawrence. "Lead Differentially Modifies Cytokine Production in Vitro and in Vivo." Toxicology and Applied Pharmacology 138 (1996): 149-157.

24. Katz, Sidney A., and Harry Salem. "The Toxicology of Chromium with Respect to its Chemical Speciation: A Review." Joumal of Applied Toxicology 13.3 (1992): 217-224.

25. Kong, In-Chul, et al. "Heavy Metal Toxicity Testing in Environmental Samples." Reviews of Environmental Contamination and Toxicology. New York: Springer-Verlag New York Inc., 1995. Vol. 142: 119-147.

26. Kulmeier, Paul D. "Partitioning of Arsenic Species in Fine Grained Soils." Journal of the Air \& Waste Management Association 47 (1997): 481-490.

27. Laperche, Valerie, et al. "Chemical and Mineralogical Characterizations of $\mathrm{Pb}$ in a Contaminated Soil: Reactions with Synthetic Apatite.” Environmental \& Science Technology 30.11 (1996): 3321-3326.

28. Lee, Suen-Zone, et al. "Predicting Soil-Water Partition Coeffiecients for Cadmium." Environmental Science \& Technology 30.12 (1996): 3418-3424.

29. Losi, M.E., C. Amrhein, and W.T. Frankenberger, Jr. "Environmental Biochemistry of Chromium." Reviews of Environmental Contamination and Toxicology. New York: Springer-Verlag New York Inc., 1994. Vol. 136: 91118.

30. Magee, Brian, Paul Anderson, and David Burnmaster. "Absorption Adjustment Factor Distributions for Polycyclic Aromatic Hydrocarbons (PAHs)." Human and Ecological Risk Assessment 2.4 (1996): 841-873.

31. Manceau, Alain, et al. "Direct Determination of Lead Speciation in Contaminated Soils by EXAFS Spectroscopy." Environmental Science \& Technology 30.5 (1996): 1540-1552.

32. Morain, Dan. "Agency Blasted Over Report on Risks on Lead." LA Times November 1, 1996.

33. Ruby, Michael V., et al. "Estimation of Lead and Arsenic Bioavailability Using a Physiologically Based Extraction Test." Environmental Science and Technology 30.2 (1996): 422-430.

34. Schoof, R.A., et al. "An Assessment of Lead Absorption from Soil Affected by Smelter Emissions." Environmental Geochemistry and Health 17 (1995): 189. 
35. Sexton, J.E., et al. "Aquatic Ecological Risk Assessment at a Zinc Smelter Site." PTI Environmental Services, Bellevue, Washington. Poster Presented at 16th Annual Meeting of the Society of Environmental Toxicology and Chemistry, November 5-9, 1995, Vancouver, BC

36. Sheppard S.C., W.G. Evanden, and W.J. Schwartz. "Heavy Metals in the Environment." Journal of Environmental Quality 24 (1995): 498-505.

37. Shrestha, Parmeshwar L. and Gerald T. Orlob. 'Multiphase Distribution of Cohesive Sediments and Heavy Metals in Estuarine Systems." Journal of Environmental Engineering 122.8 (1996): 730-

38. Smies, Maarten. "On the Relevance of Microecosystems for Risk Assessment: Some Considerations for Environmental Toxicology." Ecotoxicology and Environmental Safety 7 (1983): 355-365.

39. Sterret, S.B., et al. "Influence of Fertilizer and Sewage Sludge Compost on Yield and Heavy Metal Accumulation by Lettuce Grown in Urban Soils." Environmental Geochemistry and Health (in press).

40. Traas, Theo P., et al. "Modeling and Risk Assessment of Tributyltin Accumulation in the Food Web of a Shallow Freshwater Lake." Environmental Science \& Technology 30.4 (1996) 1227-1237.

41. Wedeen, Richard P., et al. "Absence of Tubular Proteinuria Following Environmental Exposure to Chromium." Archives of Environmental Health 51.4 (1996): 321-323. 


\section{National Environmental Policy Institute Bioavailability Policy Project}

Project Leadership

Hon. Don Ritter, Sc.D.

Chairman, NEPI

Don R. Clay, Project Director

President, Don Clay Associates

Frances Spell

Executive Director, NEPI

Project Staff

Jeffery Denit

Vice President \& Technical Director

Don Clay Associates

J. Gregory Planicka, J.D.

Deputy Director of Projects, NEPI

Amy Horner

Staff Assistant \& Meeting Coordinator, NEPI 
National EnVironmental Policy Institute

1100 SeVENTEENTH StREET, NW, WASHington, D.C. 20036 